A brief overview of the evolution and main features of the biotechnology industry

Margarida Fontes

Pedro Videira

2012

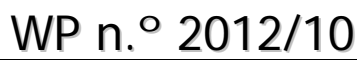

DOCUMENTO DE TRABALHO

WORKI NG PAPER

DINAMIP'CET

CENTRO DE ESTUDOS SOERE A MUDANCA
SOCIOECONOMICA E OTERAITORID

ISCTE-IUL.

FCT

Fundaçio para a Ciência e a Tecnologix 


\title{
DINAMIR'CET
}

CENTRO DE ESTUDOS SOBRE A MUDANCA

ISCTE-IUL

\section{A brief overview of the evolution and main features of the biotechnology industry}

\author{
Margarida Fontes*
}

Pedro Videira**

WP n. $.2012 / 10$

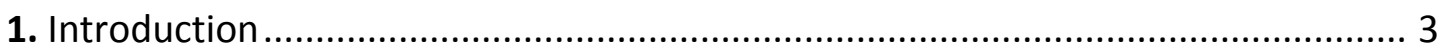

2. A brief overview of the evolution of the industry ............................................. 4

3. Dedicated biotechnology firms: business models, resources and relationships ..... 8

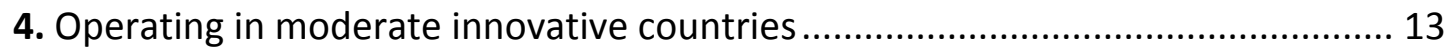

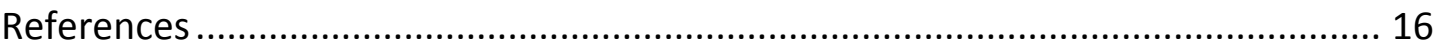

\footnotetext{
* LNEG/ UMOSE and DINÂMIA'CET - IUL.

*** DINÂMIA'CET - IUL.
} 


\title{
A brief overview of the evolution and main features of the biotechnology industry ${ }^{1}$
}

\begin{abstract}
This paper offers an overview of the origin, evolution and main features of the biotechnology industry, putting particular emphasis on the behaviour of one key actor - the dedicated biotechnology firm. It starts with a brief historical background detailing the origin and dynamics of the industry, which is followed by a more detailed examination of the firms' strategies, business models and networking behaviour. It concludes with a discussion on the constraints and opportunities faced by firms operating outside the main centres of knowledge production and business in biotechnology, as is the case of dedicated biotechnology firms located in Portugal.
\end{abstract}

\footnotetext{
${ }^{1}$ Adapted from Chapter 5 in Salavisa, I. and M. Fontes (Eds) Social Networks, Innovation and the Knowledge Economy, London: Routledge.
} 


\section{INTRODUCTION}

Biotechnology emerged in the second half of the twentieth century and has rapidly become an important locus of scientific and technological change, as well as a priority target for extensive public and private investment. It is an extremely dynamic sector, which has undergone profound changes since its origin in terms of the underlying technologies, the roles played by different actors and the business models and strategies adopted by firms. Given its economic importance and growth potential, biotechnology has become one economic pillar in the most developed countries and has been identified by several moderate innovative countries as essential for completing their transition to the knowledge economy.

Networks are a fundamental mode of organization in the industry and are essential to the success of firms, namely for those operating outside the main centres of knowledge production and business. This is mainly related to the fact that biotechnology is international in nature and is characterized by the presence of some global players that have a coordinating function, thus being able to bring small specialized firms into the value chain, whatever their location, providing that they offer specific advantages. Thus, in spite of the spatial concentration in core regions and clusters, there are opportunities for firms (and regions) outside the main centres.

However, the success of firms from more peripheral locations still requires that the national or regional system of innovation provides a favourable institutional setting, even if lacking in some resources and competences that will have to be accessed worldwide. Public policies are of the utmost importance here, namely in the creation of critical assets such as a strong scientific knowledge base and a pool of highly skilled human resources, in the support of technological entrepreneurship and in the promotion of connections between the various actors (public and private) that can contribute to the development of the industry.

This paper offers a brief overview of the evolution and main features of the biotechnology sector focusing on three main aspects: 1) a brief historical background detailing the origin and general evolution of the industry; 2) an overview of firms' strategies, business models and networking behaviour over time and; 3) a discussion on the constraints and opportunities faced by firms that are located outside the main centres of knowledge production and business. 


\section{A BRIEF OVERVIEW OF THE EVOLUTION OF THE INDUSTRY}

One striking feature of biotechnology is that, ever since its earliest beginnings in the 1970s and 1980s, networks have been at the heart of the industry. Indeed, networks are the basic organising device in the industry. This networked mode of organization emerged as a result of the division of labour between a number of actors - new dedicated biotechnology firms, large incumbent firms, universities, financing organizations - that, taken individually, only possessed part of the various competences or assets (scientific, clinical, manufacturing, legal, financial, regulatory, marketing, distribution) required to operate in the industry. Therefore, they strategically engaged in extensive interactions to meet their additional needs, leading to a multiplication of research partnerships and strategic alliances among private and public organizations (Powell et al. 1996; 2012; Orsenigo 1989).

One possible explanation for the emergence of this type of organizational structure lies in the fact that biotechnology originated from new scientific discoveries, developed outside the sector where it was first applied - pharmaceuticals - and was introduced by new entrants who were 'outsiders' to that industry. However, these new entrants were forced to establish relationships with the incumbents, who did not dominate the new knowledge but controlled the downstream assets necessary to commercialize its applications.

Since the new knowledge departed radically from the incumbents' knowledge base, they were not involved in the early development of the new technology or its applications. However, as the technology being introduced challenged the existing drug discovery processes and because it started being perceived as having the potential to address some of the industry bottlenecks, incumbents strategically engaged in partnerships with the new entrants to gain access to the new knowledge and/or to keep an eye on its developments (Arora and Gambardella 1994).

On the other hand, the new entrants were exploiting a technology based on new scientific discoveries, characterized by high novelty and uncertainty and whose development still required extensive investments in research and development (Orsenigo 1989). They were small firms, often founded by scientists and they were confronted with severe resource and competence shortages and with a market fully controlled by the incumbents. Thus, alliances with large established companies - which often assumed the form of research contracts - were critical to enable these firms to pursue the development of their technologies, as well as to guarantee their subsequent commercialization, even if this meant that incumbents reaped a substantial part of the profits from the innovation (Audretsch and Feldman 2003). 
In addition, another important actor emerged in response to the long development time-lags and high uncertainty, which required investments far beyond the capacities of the new entrants, but precluded the involvement of traditional capital sources - the venture capital firm. This made possible a new mode of financing: companies that held intangible assets (intellectual property) instead of products or services were funded on the basis of the value attributed to that intellectual property (Coriat et al. 2003). By providing both capital and business intelligence and also offering legitimacy, venture capitalists helped make the science-based firm model viable and became a critical element in the early biotechnology industry (Powell et al. 2012).

The nature of the new knowledge being exploited also meant that the new firms had to maintain close interaction with the research organizations that were leading the development of the new scientific fields. This enabled them to pursue the development of their initial technologies which often required long term research - and to retain their competitive edge over time (George et al. 2002). Those relationships were facilitated by the fact that the new firms were usually spin-offs from research organizations and their entrepreneurs were often scientists, who had been involved in the development of the technologies being exploited. Even though most firms had highly qualified research teams, the new firms' small size and scarce resources meant it was fundamental to have access to producers of new scientific knowledge, in order to complement their more specialized efforts (Zucker et al. 1998).

Thus, the early development of the industry was characterized by strong interactions between research universities that guaranteed the continuity in the production of knowledge and the new firms that were created to exploit the emerging technologies; and between these firms and established companies operating in the pharmaceutical sector, which assumed the responsibility for part or the totality of the downstream activities, including the regulatory aspects and the production and/or commercialization of the resulting products.

Subjacent to this mode of organization was a system for 'monetizing intellectual property' (Pisano 2010), consisting of three interrelated elements: technology transfer from universities to the new firm; venture capital and public equity markets that provided critical funding and rewarded the entrepreneurs, investors and universities for the risks they were taking; and established firms that accessed the intellectual property of new firms in exchange for funding their research activities. 
The mode of organization adopted in the early stages effectively shaped the development of the industry (Powell et al. 2012; McKelvey 2008). It led to the emergence of a new type of company - the dedicated biotechnology firm (DBF) - which was qualitatively different from the typical technology-based start-up that had emerged in the information technologies sector. It led to an industrial organization where there was a relatively clear division of labour between producers of scientific knowledge, dedicated biotechnology firms and firms from user sectors, all possessing complementary competences and assets. As a result, it led to a system whose functioning requires intense interactions between the various actors and thus to the development of extensive networks between them. Some authors have even argued that, in biotechnology, the locus of innovation is effectively the network (Powell et al. 1996).

This mode of organization proved highly persistent, even if some changes/adjustments in the role and position of the various actors took place over time, or when biotechnology applications extended to other user sectors or to different country contexts. The dedicated biotechnology firm remains a central actor in a 'biotechnology industry', even if its role is less relevant when it comes to the application of biotechnology to non-health related sectors, which are also those where the technology has been least pervasive (McKelvey 2005). The extent of the division of labour and the forms it assumes have changed over time, as the technology and markets evolved and as the competences and strategies of the different interveners evolved with them (Powell et al. 2005; Gottinger and Umali 2011; McKelvey et al. 2004; Queré 2003). But it remains a basic tenet of the industrial organization in biotechnology and the driver of the ever growing networking activity that characterizes it (Stuart et al. 2007; Roijakkers and Hagedoorn 2006).

There were nevertheless important changes in the strategies of the different actors and in the organization of the field that are worth considering. Over time, large established firms developed in-house biotechnology expertise, often interacting directly with universities, created biotechnology-oriented units or acquired their small biotechnology suppliers (McKelvey et al, 2004; Gottinger and Umali 2011). However, the complexity and fast pace of change in the industry knowledge base, the fact that it often originates from frontier research (which tends to give rise to a variety of search trajectories) and the need to deal with the resulting uncertainty meant that collaboration with DBFs that were exploiting new generations of knowledge remained critical (Powell et al. 2012; Orsenigo et al, 2001). In particular, the emergence of new technologies (e.g. genomics and proteomics), which are once again based on a substantially different knowledge base, required established firms to rely more strongly on collaboration with 
biotechnology firms and to establish less asymmetric alliances with them (Gottinger and Umali 2011; Queré, 2003).

Changes also took place in the case of DBFs. A few biotechnology pioneers were able to achieve some degree of vertical integration and grow, although this was not widespread (Gottinger and Umali 2011). New firms targeting application segments outside drug discovery, which had different capital and regulatory requirements and where small specialized niches could be found, engaged in the development and commercialization of own products and services, aiming at niche markets (Luukkonen 2005; Mangematin et al. 2002). Even in the drug discovery field, the emergence of the above mentioned technologies created new opportunities for firms exploiting transversal technologies and developing generic research tools that can be applied to a variety of problems (Orsenigo et al. 2001; Queré 2003). In both cases, DBFs were less dependent on alliances with one particular company, even though large companies often remained their main clients.

The division of labour also assumed different forms when biotechnology was applied to other sectors. For instance, it is less marked in agro-food, where biotechnology development is clearly dominated by large established companies that collaborate directly with research organizations (Valentin and Jensen 2003; McKelvey 2005). Here DBFs have a less prominent role, only operating in specific segments and being confined to specialized niches. A similar situation occurred when biotechnology development took place in specific country contexts where some key actors were absent or less proactive (Owen Smith et al. 2002; Luukkonen and Palmberg 2007; Fontes 2007; Gilding 2008; Finegold et al. 2004; Nosella et al. 2005).

Overall, this evolution led to a greater diversity of business models and to changes in the actors' positioning in the industrial structure. 


\section{DEDICATED BIOTECHNOLOGY FIRMS: BUSINESS MODELS, RESOURCES AND RELATIONSHIPS}

We will now turn our attention to the case of dedicated biotechnology firms (DBFs) so as to achieve a better understanding of the position of these firms in the network structure that characterizes the biotechnology industry and its implications for the type of relationships they build.

Some authors defend that biotechnology - or 'modern biotechnology' to differentiate it from traditional bio-processing activities - is not an industry, but rather a technological area that builds upon a variety of knowledge bases (e.g. molecular biology, genetic engineering, protein engineering, bioinformatics) and that is applied to a range of economic activities in different application sectors (Brink et al. 2004).

However, it can be argued that it is nevertheless possible to consider a loosely defined 'biotechnology industry', whose 'core' is composed of firms fully engaged in 'the application of scientific and engineering principles to the processing of materials by biological agents to provide goods and services' (OECD 2001). These firms interact with organizations located upstream (knowledge producers) and downstream (firms in different application sectors or specialized investors) to develop and commercialize their technologies. Those other organizations may be within or outside these loose industry boundaries, depending on their degree of involvement in biotechnology. This 'core' is, first of all, composed of entrepreneurial dedicated biotechnology firms (Powell et al. 2012). In addition, we can find subsidiaries or business units of firms operating in application sectors that have diversified into biotechnology, and thus have at least partly moved into the 'core'. Although DBFs' positioning differs across application sectors - since they are confronted with different competitive environments - it can nevertheless be argued that, overall, they remain very central to the 'industry' and play an important role in a wider 'biotechnology system' composed of all the organizations directly and indirectly involved in biotechnology-related activities.

Thus, we will subsequently consider a 'biotechnology industry' in these terms and discuss the activities of the 'core' dedicated biotechnology firms in reference to the other actors that compose the system.

As pointed out above, dedicated biotechnology firms emerged as a novel organizational form that responded to a new type of challenge: the transformation of basic science into business 
(Pisano 2006; Powell and Sandholtz 2012). These 'science-based firms' differed from other technology intensive firms in what they were extensively engaged in scientific production and not simply in the application of results from existing science. Thus, they were involved in research activities, outside the context where these activities traditionally took place - the university - and were confronted with long periods of investment in R\&D and high uncertainty, while lacking the financial and market power of the large established firm to withstand it (Pisano 2010).

The business model that resulted from the interaction between biotechnology entrepreneurs and a variety of other actors was a response to these new conditions. Powell and Sandholtz (2012: 97) offer an apt description of this process:

These scientists, financiers and business people all drew on their existing networks and prior skills to develop a form that operated according to quite different principles from either the traditional vertically organized corporate hierarchy or the university laboratory. A new model of a sciencebased company was constructed, based on fundamental scientific research, horizontal flows of information, porous organizational boundaries, a strong reliance on intellectual capital and collective know-how, and a strategy of pursuing innovation through collaborative ventures with other organizations.

This early model, which emerged in the sector where biotechnology was first applied - the pharmaceutical industry - still prevails in some biotechnology segments, in particular these concerned with the process of drug discovery and development, which remains clearly dominated by large pharmaceutical firms. In this model - which has been labelled the 'classical model' (McKelvey 2008) - biotechnology firms operate exclusively upstream: they are engaged in long-term cutting-edge research, producing new knowledge (intellectual property), which is usually patented and then sold or licensed to other firms that control the downstream assets and pursue their subsequent development. Thus DBFs are basically suppliers of knowledge with a limited connection with its application.

The 'classical model' had advantages but also revealed some weaknesses. Seen from the perspective of the DBF, it can be argued that it enabled new entrants to operate in a market dominated by powerful incumbents (Shan et al. 1994; Greis et al. 1995). Alliances not only provide access to complementary assets but also signal quality: in fact, industry analysts ascribe market value to individual firms based on the quantity and quality of their alliances (Powell et al. 1996). However, DBFs often have to pay a high price in terms of control over their assets 
(Lerner and Merges 1998): they may end up deprived of a substantial part of the profits from their innovations and can even incur the risk of appropriation of their main asset (Gans and Stern 2003). Moreover, their development beyond the stage of 'research boutique' is constrained by the asymmetry of power relative to their partners (McKelvey 2008).

For the established firm, which frequently acts as coordinator of a set of knowledge suppliers exploring a variety of research trajectories (Orsenigo et al. 2001), this model is a way of sustaining competitiveness while avoiding the early uncertainty (Gottinger and Umali 2011; Rothaermel 2001). However, uncertainty remains with regard the final outcome. Indeed, it has been observed that biotechnology alliances did not substantially increase the number of new drugs that went successfully through clinical tests and regulatory approval, nor improved the productivity in their development (Hopkins et al. 2007; Pisano 2006). As a result, large pharmaceutical companies were increasingly faced with rising R\&D expenditures, but also with growing difficulties in bringing new drugs to the market and, therefore, with decreasing profitability (Gottinger and Umali 2011; Pammolli et al. 2011). This state of affairs even led some authors to discuss whether the science-based firm and the associated model of biotechnology development is the most suitable to bring the technologies to the market in this field, or whether other institutional arrangements might prove more effective (Pisano 2010).

In the meanwhile, large pharmaceutical companies, confronted with decreasing profitability and financial restrictions in capital markets, as well as with governments' need to reduce public health care expenditure, became increasingly concerned about efficiency (Ernst \& Young 2011). This had a number of implications for the classical DBF model. Pharmaceutical companies increasingly press DBFs to pursue the development of their technologies to later stages (e.g. to clinical development), in order to obtain greater evidence of their efficacy before licensing, or bind licensing revenues more closely to the proof of such efficacy (Pisano 2006). According to some industry observers, this context may have reduced the opportunities for the traditional venture-capital funded highly exploratory research projects, unless they are perceived as having clearly differentiated assets and high value platforms (Ernst \& Young 2011).

But it has also generated growing opportunities for firms offering technologies that can increase the productivity of the drug discovery-development process. These firms often have a platform technology that can be used to offer services or develop products that add value to the R\&D process of their clients (Amir-Aslani and Mangematin 2010; McKelvey 2008). Other firms have identified opportunities for offering less research-intensive but highly specialized services, 
creating value through the orchestration and/or recombination of knowledge from different origins, which they articulate in new ways (Sabatier et al. 2010). While being similarly engaged in alliances with large pharmaceutical companies (which are their main clients), these firms may have a wider margin of manoeuvre in market terms (Queré 2003). Some of them are simultaneously engaged in developing their own drug targets, thus exhibiting hybrid business models (Willemstein et al 2007).

Indeed, hybrid models are increasingly present among firms that are involved in long-term drug discovery research with a view to licensing but that, in the meanwhile, engage in other product or service oriented activities, which provide them with a faster path to revenue generation (McKelvey 2008; Sabatier et al. 2010; Wall 2010). Some authors have also noted the emergence of non-research companies that chose to concentrate exclusively on development activities, focusing on products that are in later stages of clinical development, often outlicensed by other companies (McKelvey 2008; Wall 2010). Finally, it is possible to find some DBFs that were able to evolve towards drug development (Kollmer and Dowling 2004; Gottinger and Umali 2011) thus becoming vertically integrated companies. This move is sometimes associated with niche drugs targeting small markets (Luukkonen 2005).

In the health segments outside the drug discovery area, organizational solutions are more varied. Though still present, the 'classical model' is much less prevalent. Firms are more likely to be involved in the production and commercialization of their own products or services, although the actual performance of some of these functions can be subcontracted (Luukkonen 2005; Mangematin et al. 2002). However, it is also possible to find firms exhibiting a diversity of hybrid business models, involving combination(s) of own development, licensing and contract research (Lowe and Gertler 2009; Kollmer and Dowling 2004; Willemstein et al 2007). This may involve combining activities in drug discovery and in other areas that offer faster and less risky commercial opportunities. Interestingly, it was found that firms combining the two models tend to adopt different alliance strategies for each activity (Luukkonen 2005).

It should nevertheless be noticed that different types of company have been present since the early stages of the industry, despite the greater focus on the 'classical model'. In a study of the emergence of the biotechnology industry, Powell and Sandholtz (2012) argue that in parallel with the science-based model that introduced a radically new way of doing business - which they label as 'in business to do research' - it was possible to find a number of other business models, which they describe as variations of a different entrepreneurial behaviour - 'in research 
to do business'. The latter were closer to the typical technology-based start-up: they had an explicit commercial orientation, science and scientists assumed a less prominent role ('science took a back seat to commercial goals') and their activities were decisively focused on bringing new biotechnology products and services to the market.

The case of dedicated biotechnology firms targeting other user sectors such as agriculture, food or energy/environment is much less studied. However, the limited research available suggests that there is a lower incidence of DBFs in the segments where biotechnology started being applied, and that these DBFs tend to be more similar to those outside drug-discovery segments (Blank 2008; Valentin and Jensen 2003; Audretsch and Feldman 2003). Also, in many of these user sectors, large established firms have a more prominent role, establishing direct collaboration with universities and developing in-house competences in the areas where they wish to operate. They often dominate key application markets and thus DBFs tend to target niche markets. Product development is usually faster and less costly than in pharmaceuticals and thus DBFs are often product-oriented, even if commercialization is sometimes carried out by other firms. They can also offer contract research or specialized services. While this does not mean that licensing is completely absent, it is much less frequent. Thus, alliances with large firms are also present but are more clearly commercial.

The above account shows that dedicated biotechnology firms are not a homogeneous group. Firms operate under different business models - including some hybrid ones - even though some modes of doing business are more dominant in some application segments (McKelvey 2008). These models range from firms that are exclusively concerned with developing upstream research activities and selling the resulting knowledge and technologies, to firms that are more or less fully engaged in the development, manufacturing and commercialization of own products or services, and thus in the performance of the associated functions. Thus, while DBFs can be generically described as playing an important role in a value chain that links basic science to commercial applications (Stuart et al. 2007), different firms have distinct positions in that value chain. This means that they perform specific types of activity, which require different types and amounts of resources and lead to the establishment of varying types of external relationships. The objective of these relationships can be either to obtain the missing resources, or simply to avoid involvement in the activities that require them (Arora et al. 2001). 


\section{OPERATING IN MODERATE INNOVATIVE COUNTRIES}

In spite of the global nature of knowledge and business in biotechnology - which both forces the firms to be internationally connected and reinforces their exposure to change - the institutional setting of a given national or regional system of innovation has a strong impact on the formation, survival and growth of new firms (Owen-Smith et al. 2002; Bartholomew 1997; Casper and Kettler 2001; Gertler and Vinodrai 2009). It influences the resources available and the conditions in which these can be accessed, thus affecting the creation decision and shaping firms’ business model and networking strategies.

The location of the firm is thus a significant factor when analysing firms' strategic choices. Since we are particularly interested in the case of countries that can be described as 'moderate innovators' (European Commission 2011) ${ }^{2}$, it is relevant to discuss the implications of the conditions found in these contexts for the behaviour of new biotechnology firms.

As shown in the previous sections, dedicated biotechnology firms are strongly interconnected with a variety of other actors that are critical for the development and commercialization of the technologies they are exploiting. In addition, it was observed that firms can adopt different business models, which correspond to specific modes of capturing the value of their technological knowledge. These business models are partly determined by the competitive environment in the application segments firms choose to target. But they are also the result of entrepreneurs' strategic choices regarding the type of activity to pursue, which will take into account the nature of their knowledge assets and the conditions concerning the access to the resources necessary to transform these assets into products or services and to commercialize them (Gans and Stern 2003; Kasch and Dowling 2008; Conceição et al. 2012).

Different business models require distinct combinations of resources, which will be at least partly external to the firm. In the case of start-ups created to exploit a new technology, a substantial part of the non-technological resources - and perhaps a non-negligible part of technological resources - will generally need to be searched outside the firm boundaries (Arora et al. 2001). Thus, the entrepreneurs' perceptions of the availability of these resources in their

\footnotetext{
${ }^{2}$ The expression was coined by the European Commission that devised an instrument to measure and compare the innovative performance of the member states, based on a composite indicator (building on data for 24 indicators): the European Innovation Scoreboard. Innovation leaders have a performance that is $20 \%$ or more above that of the average performance of the EU27; Innovation followers are less than 20\% above but more than 10\% below; Moderate innovators are less than 10\% below but more than $50 \%$ below; Modest innovators are below $50 \%$.
} 
environment and of the conditions in which they can be accessed (including the possible costs of searching for them elsewhere) are likely to influence the decision on the business model to adopt (Conceição et al. 2012).

Once that decision is made, the actual conditions in terms of resource availability and the options made about modes of resource access will shape the network of relationships established by the new firm. Difficulties confronted in the path chosen, or the identification of alternative paths with greater perspectives of success may make firms adjust or even significantly change their business model and thus their resources access networks (Druilhe and Garnsey 2004). But even though changes are likely to occur over time, early choices on competence development and resource mobilization are important (Conceição et al. 2012), because they can have an 'imprinting effect' upon the firm, constraining its subsequent evolution (Eisenhardt and Schoonhoven 1990).

These considerations may help explain the behaviour of DBFs in the particular context of moderate innovative countries (Salavisa and Vali 2012). These firms operate in environments that are peripheral to the main concentrations of knowledge and business in biotechnology and that often have no specialization in the sectors that are the main drivers of this industry (Fontes 2007). These environments also tend to be characterized by a limited development of technology intensive sectors in general (Salavisa, 2007). Thus, in addition to missing or underdeveloped biotechnology-related competences and resources (and their potential suppliers), other generic resources critical to this type of firm - e.g. capital and a set of specialized services - are also likely to be in limited supply (Degroof and Roberts 2004).

Biotechnology entrepreneurship is a relatively recent phenomenon in this type of economies. However biotechnology is likely to have assumed an important role in both the scientific and the innovation policies of several of these countries (Rosiello and Orsenigo 2008). This has often been reflected in the development of scientific competences and the creation of a pool of human resources in biotechnology-related fields, as well in the introduction of extensive public (and sometimes private) incentives for science-based entrepreneurship (Feldman and Schipper 2007). This combination of supply side conditions and incentives has encouraged new firm formation, to some extent offsetting the environmental limitations (Fontes 2007).

Indeed, studies in more peripheral contexts confirmed that while it can be more complex for DBFs to be created and survive in this type of environment, firms tend to adjust their activities 
to the conditions in which they operate and are able to develop specific strategies to compensate for their environmental shortcomings (Fontes 2005; Gilding 2008; Bigliardi et al. 2005). In particular, several studies have highlighted the importance of international networks in gaining access to technological and non-technological competences and resources that complement those available locally or compensate for their absence (e.g. Gertler and Levitte 2005; Birch and Cumbers 2009; Luukkonen 2005; Breznitz and Tahvanainen 2010; Cooke et al. 2006; Pitt et al. 2006). In the case of Portugal, recent research has shown that new firms benefit from both the existence of indigenous sources of scientific knowledge and complementary assets - with which close connections are maintained - and the establishment of international knowledge and market sourcing relations with more advanced contexts, whose importance tends to increase through the firms’ life-cycle (Fontes 2006, 2007; Fontes et al, 2009).

It can be concluded that the strategies of dedicated biotechnology firms vary according to industry specific factors - such as the sector of application, the nature of the underlying technologies, the changes in competitive conditions and their respective impacts on firms' business models; but location-specific factors, which add additional elements to firms' decision making process, also lead to varying strategies. When analysing the behaviour of firms located in moderate innovative countries, the combination of these different factors must always be taken into consideration. 


\section{REFERENCES}

AMIR-ASLANI, A., MANGEMATIN, V. (2010) The future of drug discovery and development: Shifting emphasis towards personalized medicine, Technological Forecasting and Social Change, 77: 203-217.

ARORA, A, FOSFURI, A and GAMBARDELLA, A (2001) Markets for technology and their implications for corporate strategies, Industrial and Corporate Change, 10: 419-451.

ARORA, A. and GAMBARDELLA, A. (1994) Evaluating technological information and utilizing it: Scientific knowledge, technological capability, and external linkages in biotechnology, Journal of Economic Behavior \& Organization, 24: 91-114.

AUDRETSCH, D. and FELDMAN, M. (2003) Small-Firm Strategic Research Partnerships: The Case of Biotechnology, Technology Analysis \& Strategic Management, 15: 273-288.

BARTHOLOMEW, S. (1997) National systems of biotechnology innovation: Complex interdependence in the global system, Journal of International Business Studies, 28 (2): 241266.

BIGLIARDI, B., NOSELLA, A. and VERBANO, C. (2005) Business models in Italian biotechnology industry: a quantitative analysis, Technovation, 25: 1299-1306.

BIRCH, K. and CUMBERS, A. (2009) Beyond Clusters: The Implications of Life Science Commodity Chains for Less-favoured Regions, Centre for Public Policy for Regions, Working Paper No.19 [http://www.cppr.ac.uk/media/media_118690_en.pdf - last accessed 26 October 2012].

BLANK, S. (2008) Insiders Views on Business Models Used by Small Agricultural Biotechnology Firms: Economic Implications for the Emerging Global Industry, AgBioForum, 11(2): 71-81.

BREZNITZ, S. M. and TAHVANAINEN, A.J. (2010) Cluster sustainability in peripheral regions: A case study on Israel's and Finland's biotechnology industries. Keskusteluaiheita, Discussion papers, No. 1212, Helsinki: ETLA, The Research Institute of the Finnish Economy. [http://www.etla.fi/files/2440_Dp1212.pdf - last accessed 26 October 2012]. 
BRINK, J., M. MCKELVEY and K. SMITH (2004) Conceptualising and Measuring Modern Biotechnology, in McKelvey, M., Rickne, A., Laage-Hellman, J. (eds.) (2004) The Economic Dynamics of Modern Biotechnology, Cheltenham: Edward Elgar Publishers.

CASPER, S. and KETTLER, H. (2001) National Institutional Frameworks and the Hybridization of Entrepreneurial Business Models: The German and UK Biotechnology Sectors, Industry and Innovation, 8(1): 5- 30.

CONCEIÇÃO, O., FONTES, M. and CALAPEZ, T. (2012) The commercialisation decisions of research-based spin-off: targeting the market for technologies, Technovation, 32: 43-56.

COOKE, P., KAUfMANN, D., LEVIN, C. and WILSON, R. (2006) The Biosciences Knowledge Value Chain and Comparative Incubation Models, Journal of Technology Transfer, 31: 115-129.

CORIAT, B., ORSI, F. and WEINSTEIN, O. (2003) Does biotech reflect a new science-based innovation regime? Industry and Innovation, 10(3): 231 - 253.

DEGROOF, J.J. and ROBERTS, E.B. (2004) Overcoming Weak Entrepreneurial Infrastructures for Academic Spin-Off Ventures. Journal of Technology Transfer, 29(3-4): 327-352.

DRUILHE, C. and GARNSEY, E. (2004) Do academic spin-outs differ and does it matter? Journal of Technology Transfer, 29(3-4): 269-285.

EISENHARDT K. and SCHOONHOVEN, K. (1990) Organizational Growth: Linking Founding Team, Strategy, Environment, and Growth among U.S. Semiconductor Ventures, 1978-1988. Administrative Science Quarterly, 40: 84-110.

ERNST \& YOUNG (2011) Beyond Borders: Global Biotechnology Reports, [http://www.ey.com/Publication/vwLUAssets/Beyond_borders_global_biotechnology_report_2 011/\$FILE/Beyond_borders_global_biotechnology_report_2011.pdf - last accessed 26 October 2012].

EUROPEAN COMMISSION (2011) Innovation Union Scoreboard 2010. The Innovation Union's performance scoreboard for research and innovation, Brussels: PRO INNO Europe.

FELDMAN, M.P. and SCHIPPER, H. (2007) Bringing science to life: an overview of countries outside of North America, Journal of Technology Transfer, 32: 297-302. 
FINEGOLD D., WONG P. K. and CHEAH T.C. (2004) Adapting a foreign direct investment strategy to the knowledge economy: the case of Singapore's emerging biotechnology cluster, Environmental Planning Studies, 12: 921-941.

FONTES, M. (2007) Technological entrepreneurship and capability building in biotechnology, Technology Analysis and Strategic Management, 19(3): 351-367.

FONTES, M. (2006) Knowledge access at distance: strategies and practices of new biotechnology firms in emerging locations, in P. Cooke and A. Piccaluga (eds.) Regional Development in the Knowledge Economy, London: Routledge, pp. 135-159.

FONTES, M. (2005) Distant Networking: The Knowledge Acquisition Strategies of 'OutCluster’ Biotechnology Firms, European Planning Studies, 13 (6): 899-920.

FONTES, M., SOUSA, C. and VIDEIRA, P. (2009) Knowledge access and location decisions in biotechnology: the spatial dimension of social networks, DINAMIA Working Papers nº 2009/79, Lisboa: DINAMIA.

[https://repositorio-iul.iscte.pt/bitstream/10071/3229/1/DINAMIA_WP_2009-79.pdf-last accessed 26 October 2012].

GANS, J. and STERN, S. (2003) The Product Market and the Market for "Ideas": Commercialization Strategies for Technology Entrepreneurs, Research Policy, 32:333- 350.

GEORGE, G., ZAHRA, S.A., D. and WOOD D.R. (2002) The effects of business-university alliances on innovative output and financial performance: a study of publicly traded biotechnology companies, Journal of Business Venturing, 17: 577-609.

GERTLER, M.S., LEVITTE, Y.M. (2005) Local Nodes in Global Networks: The Geography of Knowledge Flows in Biotechnology Innovation, Industry and Innovation, 12(4): 487-507.

GERTLER, M. S. and VINODRAI, T. (2009) Life Sciences and Regional Innovation: One Path or Many? European Planning Studies, 17(2): 235-261.

GILDING, M. (2008) The 'tyranny of distance': Biotechnology networks and clusters in the antipodes, Research Policy, 37: 1132-1144.

GOTTINGER, H. and UMALI, C. (2011) Organizational Entrepreneurship: A Historical Overview on Industry Alliances in Biotech and Pharmaceuticals, The Open Business Journal, 4: 14-27. 
GREIS, N.P., DIBNER, M.D. and BEAN, A.S. (1995) External partnering as a response to innovation barriers and global competition in biotechnology, Research Policy, 24: 609-630.

HOPKINS, M., M., PAUL, A. MARTIN, P. NIGHTINGALE, A. KRAFT and S. MAHDI, (2007) The myth of the biotech revolution: An assessment of technological, clinical and organisational change, Research Policy, 36: 566-589.

KASCH, S. and DOWLING, M. (2008) Commercialization strategies of young biotechnology firms: An empirical analysis of the U.S. industry, Research Policy, 37: 1765-1777.

KOLLMER, H. and DOWLING, M. (2004) Licensing as a Commercialization Strategy for New, Technology-Based Firms, Research Policy, 33: 1141-1151.

LERNER, J. and MERGES, R.P. (1998) The control of technology alliances: An empirical analysis of the biotechnology industry, The Journal of Industrial Economics, 46: 125-156.

LOWE, N. J. and GERTLER, M.S. (2009) Building on Diversity: Institutional Foundations of Hybrid Strategies in Toronto's Life Sciences Complex, Regional Studies, 43: 589 - 603.

LUUKKONEN, T. (2005) Variability in organisational forms of biotechnology firm, Research Policy, 34: 555-70.

LUUKKONEN, T. and PALMBERG, C. (2007) Living up to the Expectations Set by ICT? The Case of Biotechnology Commercialisation in Finland, Technology Analysis \& Strategic Management, 19: 329-349.

MANGEMATIN, V, LEMARIÉ, S., BOISSIN, J.P., CATHERINE, D., COROLLEUR, F., CORONINI, R. and TROMMETTER, M. (2002) Development of SMEs and Heterogeneity of Trajectories: The Case of Biotechnology in France, Research Policy, 32: 621-638.

MCKELVEY, M. (2008) Health Biotechnology: Emerging Business Models and Institutional Drivers' in OECD International Futures Project on The Bioeconomy to 2030: Designing a Policy Agenda, Background Documents [http://www.oecd.org/dataoecd/12/29/ 40923107.pdf last accessed 26 October 2012].

MCKELVEY, M. (2005) What drives innovation processes in modern biotechnology and open source software?, Innovation: Management, Policy \& Practice, 7: 79-95. 
MCKELVEY, M., ORSENIGO, L. and PAMMOLLI, F. (2004) Pharmaceuticals analyzed through the lens of a sectoral innovation system, in F. Malerba (ed) Sectoral Systems of Innovation Concepts, Issues and Analyses of Six Major Sectors in Europe, Cambridge University Press, pp. 73-120.

NOSEllA, A., PETRONI, G. and VERBANO, C. (2005) Characteristics of the Italian biotechnology industry and new business models: the initial results of an empirical study, Technovation, 25: 841-855.

OECD (2001) A Statistical Framework for Biotechnology Statistics, DSTI/EAS/STP/ NESTI (2001) 39, Paris: OECD.

ORSENIGO L., (1989) The Emergence of Biotechnology, London: Pinter Publishers.

ORSENIGO, L., PAMMOLli, F. and RICCABONI, M. (2001) Technological Change and Network Dynamics. Lessons from the Pharmaceutical, Research Policy, 30:485- 508.

OWEN-SMITH, J., RICCABONI, M., PAMMOLLI, F. and POWELL, W. (2002) A Comparison of U.S. and European University-Industry Relations in the Life Sciences, Management Science, 48(1): 24-43.

PAMMOLLI, F., MAGAZZINI, L. and RICCABONI, M. (2011) The productivity crisis in pharmaceutical R\&D, Nature Reviews Drug Discovery, 10: 428-438.

PISANO, G. (2010) The evolution of science-based business: innovating how we innovate, Industrial and Corporate Change, 19: 465-482.

PISANO, G. (2006) Can Science Be a Business? Lessons from Biotech, Harvard Business Review, October 2006: 114-125.

PITT, L., VAN DER MERWE, R., BERTHON , P. SALEHI-SANGARI, E. and CARUANA, A. (2006) Global alliance networks: A comparison of biotech SMEs in Sweden and Australia, Industrial Marketing Management 35: 600-610.

POWELL, W.W. and SANDHOLTZ, K. (2012) Amphibious Entrepreneurs and the Emergence of New Organizational Forms, Strategic Entrepreneurship Journal, 6: 94-115. 
POWELL, W.W., PACKALEN, K. and WHITTINGTON, K. (2012) Organizational and institutional genesis: the emergence of high-tech clusters in the life sciences, in J. Padgett and W. Powell (eds.) The Emergence of Organization and Markets, Princeton: Princeton University Press.

POWELL, W.W., WHITE, D.R. KOPUT, K.W. and OWEN-SMITH, J. (2005) Network dynamics and field evolution: The growth of inter-organizational collaboration in the life sciences, American Journal of Sociology 110:1132-1205.

POWELL, W.W., KOPUT, K.W. and SMITH-DOERR, L. (1996) Interorganizational collaboration and the locus of innovation: Networks of learning in biotechnology, Administrative Science Quarterly, 41:116-45.

QUERÉ, M. (2003) Knowledge dynamics: Biotechnology's incursion into the pharmaceutical industry, Industry and Innovation, 10: 255-273.

ROIJAKKERS, N. and HAGEDOORN, J. (2006) Inter-firm R\&D partnering in pharmaceutical biotechnology since 1975: Trends, patterns, and networks, Research Policy, 35: 431-446.

ROSIELlo, A. and ORSENIGO, L. (2008) A Critical Assessment of Regional Innovation Policy in Pharmaceutical Biotechnology, European Planning Studies, 16(3): 337-357.

ROTHAERMEL, F.T. (2001) Complementary assets, strategic alliances, and the incumbent's advantage: an empirical study of industry and firm effects in the biopharmaceutical industry, Research Policy, 30: 1235-1251.

SABATIER, V., MANGEMATIN, V. and ROUSSELLE, T. (2010) From Recipe to Dinner: Business Model Portfolios in the European Biopharmaceutical Industry, Long Range Planning, 43: 431-447.

SALAVISA, I. and VALI, C. (2012) Knowledge intensive sectors in moderate innovative countries in Europe: overcoming the missing links, stepping over barriers, in Salavisa, I. and Fontes, M. (eds.) Social Networks, Innovation and the Knowledge Economy, London: Routledge.

SALAVISA (2007) Os países intermédios na encruzilhada: globalização, sociedade do conhecimento e suas consequências, in I. Salavisa, W. Rodrigues and S. Mendonça (eds.) Inovação e Globalização - estratégias para o desenvolvimento económico e territorial, Porto: 
Campo das Letras.

SHAN, W., WALKER, G., KOGUT, B. (1994) Interfirm cooperation and startup innovation in the biotechnology industry, Strategic Management Journal, 15: 387-394.

STUART, T. E., OZDEMIR, S.Z. and DING, W.W. (2007) Vertical alliance networks: The case of university-biotechnology-pharmaceutical alliance chains, Research Policy, 36: 477-498.

VALENTIN, F. and JENSEN, R.L. (2003) Discontinuities and distributed Innovation: the case of Biotechnology in food Processing, Industry and Innovation, 10(3): 275-310.

WALL, N.T. (2010) Evolution of business models in the human therapeutics sector: How and why are firms changing? DRUID-DIME Academy Winter PhD Conference, Aalborg, Denmark, January 21 - 23. [http://www2.druid.dk/conferences/viewpaper.php?id=500773\&cf=44 - last accessed 26 October 2012].

WILLEMSTEIN, L., VAN DER VALK, T. and MEEUS, M.T.H. (2007) Dynamics in business models: An empirical analysis of medical biotechnology firms in the Netherlands, Technovation, 27: 221-232.

ZUCKER L., DARBY M., BREWER M., 1998, Intellectual Human Capital and the Birth of U.S. Biotechnology Enterprises, American Economic Review, 88(1): 290-306. 